\title{
Navigating the Tensions in Collaborative Watershed Governance: Water Governance and Indigenous Communities in British Columbia, Canada
}

\section{Rosie Simms}

simms.rosie@alumni.ubc.ca

University of British Columbia, June 2016

Final version: Simms, R., Harris, L., Joe, N., \& Bakker, K. (2016). Navigating the tensions in collaborative watershed governance: Water governance and indigenous communities in British Columbia, Canada. Geoforum, 73, 6-16. doi:10.1016/j.geoforum.2016.04.005

Citations of this work should use the final version as noted above 


\section{TABLE OF CONTENTS}

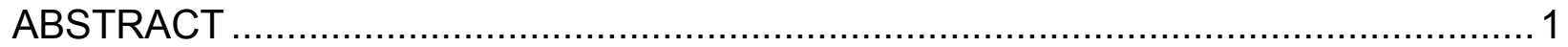

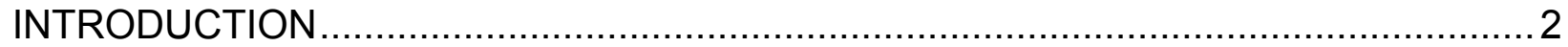

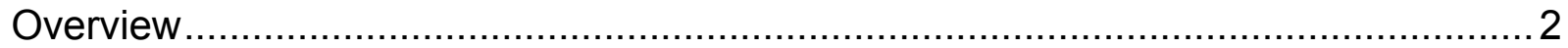

CONTEXT: DRIVERS OF WATER GOVERNANCE REFORM IN BC .....................5

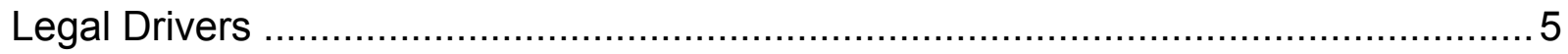

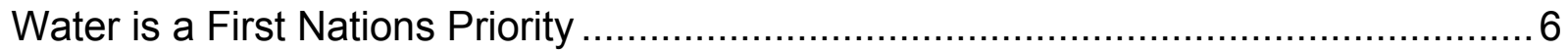

Trends in Water Governance Scholarship.................................................. 6

RESEARCH APPROACH AND METHODOLOGY .......................................... 8

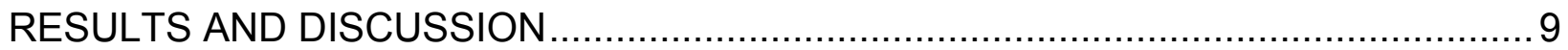

Results and Discussion Part 1: What are the Persistent Governance Challenges? ....9

Results and Discussion Part 2: Collaborative Watershed Governance in BC:

Implications for First Nations' Engagement in Water Governance ......................... 12

BEYOND COLONIAL WATER GOVERNANCe ............................................. 19

Imagining Alternative Pathways Towards Collaborative Water Governance ............. 19

Enabling Steps Towards Collaborative Water Governance ................................ 22

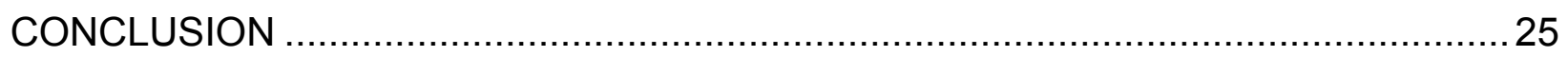

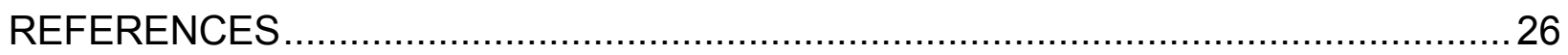

Acknowledgements:

The authors would like to acknowledge the support of the Water, Economics, Policy and Governance Network for this project. We also extend our gratitude to the LSIB Chief and Council and community members, and to Gwen Bridge, Tessa Terbasket, and Tracy Lawlor for their project support. Emma Norman and Jana Kotaska helped refine earlier versions of this work. 


\section{ABSTRACT}

First Nations in British Columbia (BC), Canada, have historically been-and largely continue to be-excluded from colonial governments' decision-making and management frameworks for fresh water. However, in light of recent legal and legislative changes, and also changes in water governance and policy, there is growing emphasis in scholarship and among legal, policy and advocacy communities on shifting water governance away from a centralized single authority towards an approach that is watershed-based, collaborative, and involves First Nations as central to decisionmaking processes. Drawing on community-based research, interviews with First Nations natural resource staff and community members, and document review, the paper analyzes the tensions in collaborative water governance, by identifying First Nations' concerns within the current water governance system and exploring how a move towards collaborative watershed governance may serve to either address, or further entrench, these concerns. This paper concludes with recommendations for collaborative water governance frameworks which are specifically focused on British Columbia, but which have relevance to broader debates over Indigenous water governance.

Keywords: collaborative water governance, First Nations, British Columbia, watersheds 


\section{INTRODUCTION}

\section{Overview}

Indigenous ${ }^{1}$ peoples in Canada have historically been-and largely continue to beexcluded from colonial governments' decision-making and management frameworks for fresh water. The existing colonial water governance system ${ }^{2}$ is predicated largely on provincial government control over decisions related to water access and use, and the Canadian government (referred to as the "Crown") asserts exclusive ownership of all ground and surface water.

Today, however, there is growing interest and movement towards a renewed set of principles and relationships for Indigenous water governance in Canada. This parallels international debates over Indigenous water rights, particularly in Latin America and Australia (Bartlett 1998; Basdeo \& Bharadwaj 2013; BCAFN 2010; Boelens 2014; 1997; Blackstock 2001; Budds \& Hinojosa 2012; Getches 2005; Mascarenhas 2007; Matsui 2009; Passelac-Ross 2011; Perreault 2005, 2008; Rizvi et al 2013; Singh 2006; Thorson et al 2006; Toussaint et al 2005; von der Porten 2012; von der Porten \& de Loë 2013a, 2013b, 2014; Walkem 2007; Wilson 2014). Notable in the Canadian case is the fact that evolving legal frameworks imply new approaches to Indigenous title, rights, and traditional territories and hence expanded (and indeed potentially unprecedented) roles for Indigenous peoples in water governance, paralleling evolving frameworks for Indigenous law more generally (Basdeo \& Bharadwaj 2013; Borrows 1997; Phare 2009, 2011; von der Porten \& de Loë, 2014; Walkem 2007). However, although evolving jurisprudence creates expanded water rights and opportunities for Indigenous communities to participate in governance processes, there is significant uncertainty with respect to processes, scope, and uptake. This is a particularly critical issue for Indigenous communities currently grappling with access to safe water, and with associated health and livelihood issues in the context of climate change (Basdeo \& Bharadwaj 2013).

These debates are particularly acute in Canada's western-most province of British Columbia, a jurisdiction in which formal treaties were never signed between the

\footnotetext{
${ }^{1}$ The term "Indigenous" refers to First Nations, Inuit, Métis peoples, and also serves as an inclusive reference to communities that claim a historical continuity with their original territories (Corntassel 2003).

${ }^{2}$ The term colonial water governance refers to Crown-implemented decision-making frameworks for water in Canada that set out who decides and who is accountable; what the parameters of the decisions are; and how the decisions are made. This includes the colonial legal frameworks for water and the existing division of powers and responsibilities. Although colonial water governance processes pertain to and impact Indigenous peoples, Indigenous input, interests and knowledges are often excluded from colonial governments' political, organizational, and administrative processes for water.
} 
Crown and Indigenous communities - which hold full rights to land and water, as recognized by Supreme Court decisions in recent years. Debates over Indigenous rights to water intersect with broader trends in water governance, including growing support for shifting water governance in BC towards an approach that is watershed-based ${ }^{3}$, collaborative, and involves Indigenous peoples more centrally and meaningfully in decision-making ${ }^{4}$ (Fraser Basin Council 2012; Brandes \& O'Riordan 2014).

In light of these issues, this paper explores Indigenous communities' perspectives on reforms to colonial water governance systems. Our rationale stems from Cohen and Davidson's (2011) critique of watershed-based governance, writ large: "Watersheds may not be appropriate in cases where re-scaling is being undertaken to address persistent governance challenges, such as lack of monitoring and enforcement, without concomitant attention to the underlying sources of the problem; such cases, we suggest, perpetuate rather than solve governance failures" (9). This paper considers both where collaborative watershed governance ${ }^{5}$ has potential to respond to some outstanding issues that First Nations have identified, as well as ongoing issues it will have to contend with, and where it still may fall short of addressing persistent governance challenges.

The paper is organized into 6 sections. Following from this introduction, Section 2 provides detail on the context and drivers of water governance reform in $\mathrm{BC}$. In section 3 , we give a brief overview of the methods used in this research. Section 4 is divided in two parts. The first part presents an overview of persistent governance challenges as described by different First Nations interviewees and identified through document review. The second part of section 4 discusses how the transition towards collaborative watershed governance in BC may 'articulate with' the governance challenges identified in part one. For section 5 we offer a discussion of alternative water governance frameworks for consideration, including several that may facilitate meaningful participation of First Nations in BC's ongoing water governance reform. Finally, in

\footnotetext{
${ }^{3}$ Watersheds are commonly understood to be "areas of land draining into a common body of water, such as a lake, river, or ocean", although they are not scientifically given, and often contested (Cohen 2012: 2207).

${ }^{4}$ A "Statement of Support for B.C. Water Sustainability Act and Regulations" was jointly prepared by advocacy groups and three universities to urge the BC government to ensure First Nations are meaningfully engaged and adequate resourcing will be provided to enforce the new Act. See Statement of Support, 2014.

${ }^{5}$ Collaborative watershed governance and co-governance are distinct concepts: we suggest that there are fundamental differences in how these two concepts address power sharing and Indigenous rights and authority: from collaborative processes, in which First Nations play a consultative or advisory role, to cogovernance in which First Nations and colonial governments co-create shared forms of jurisdiction, and First Nations have substantial or legally-binding authority (Kotaska 2013; Goetze 2005; Tipa and Welch 2006). The two terms are used accordingly throughout this paper.
} 
section 6 , we summarize our research with concluding remarks. 


\section{CONTEXT: DRIVERS OF WATER GOVERNANCE REFORM IN BC}

The primary drivers for current water governance reform in BC generally fall into three key categories. The first category involves the dynamic legal landscape for Indigenous peoples in Canada more broadly, and the recent changes in the legislative framework for water in BC. The second category speaks to the priority that Indigenous communities in $\mathrm{BC}$ give to water and water governance. Finally, the third category draws from broader calls for water governance reform, including growing interest from academic and advocacy communities in creating more collaborative and participatory forms of water governance.

\section{Legal Drivers}

The legal landscape for First Nations in $\mathrm{BC}$ is unique in Canada in that very few historic treaties were signed in the province (with the exception of the Douglas Treaties on Vancouver Island and a section of north-eastern BC which falls under Treaty 8), and few treaties have been finalized through the modern treaty process (Madill 1981; Kotaska 2013). Thus, the legal fact stands that the majority of the province is unceded First Nations' territory (FNLC 2011; UBCIC 2010, 2011; Walkem 2004). Through a series of legal decisions ${ }^{6}$, most recently the 2014 Tsihlqot'in case, the Supreme Court of Canada has clearly established that Aboriginal rights and title can no longer be legally ignored and that First Nations must be involved at a strategic level in decisions that impact their territories (Kotaska 2013; Morellato 2008). As the legal landscape of rights and title continues to evolve, so too do the requirements and impetus for provincial and federal governments to engage meaningfully with First Nations in land and water governance and management. These changing legal requirements constitute a critical "precondition" of collaborative or co-governance-based approaches to water governance, not only in BC, but across the entire country (Plummer \& Fitzgibbon 2004).

Legal changes specific to the realm of fresh water are driving water governance reform in BC. While there are numerous existing watershed stewardship and governance entities, some of which involve First Nations, these existing arrangements

\footnotetext{
${ }^{6}$ From the 1970s through to present there have been a series of pivotal court cases on Aboriginal rights and title. Critical outcomes from these cases include: confirmation that Aboriginal title to land existed at the time of the 1763 Royal Proclamation (Calder v. British Columbia [1973]) and continues to exist (Delgamuuk'w v. British Columbia [1997]); declaration of Aboriginal title to specific lands (Tsilhqot'in Nation v. British Columbia [2014]); establishment of criteria to determine whether an Aboriginal right exists and how a government may be justified to infringe upon it (e.g. R v. Sparrow [1990]); and development of requirements for consultation and accommodation (e.g. Haida Nation v. British Columbia [2004]). Section 35(1) of the 1982 Canadian Constitution recognizes and affirms existing Aboriginal and treaty rights.
} 
have thus far "emerged organically, and are not directed by an overall provincial law or policy" (Nowlan \& Bakker 2007: 14). Now, however, BC's new Water Sustainability Act (WSA or Act), which came into force in early 2016, presents the opportunity for formalized governance shifts to augment and substantiate the role of these entities. Although the WSA itself does not specify the form of governance that could be developed, the 2013 legislative proposal stipulates a "collaborative public process" (60) and "greater involvement and participation for First Nations in water management and watershed planning processes" (6). Thus, there are broad suggestions that the Province may work towards establishing or supporting collaborative watershed governance entities (e.g. authorities or watershed boards) with First Nations representation.

\section{Water is a First Nations Priority}

In addition to the legal drivers mentioned above, First Nations across BC have also clearly identified that water and water governance are priority areas of concern within broader efforts to assert Indigenous rights and governance (UBCIC 2015). While being mindful of the diversity of First Nations and wary of making essentialist claims, the cultural, spiritual, and socioeconomic values of water to Indigenous peoples are widely depicted-descriptions of water as a powerful medicine and sacred resource, as the lifeblood of the land, and as a relative that must be respected and cared for, are echoed by Indigenous communities and organizations, and scholars throughout the literature (Blackstock 2001; LaBoucane-Benson et al. 2012; McGregor 2012, 2013; Sanderson 2008; Walkem 2004; Wilson 2014). These were also key themes highlighted by First Nations submissions as part of the WSA consultation process (cf. Program on Water Governance report, forthcoming).

Strategic planning around water is a prominent aspect of the portfolios of a range of First Nations organizations, including the First Nations Fisheries Council of BC and the BC Assembly of First Nations (see Water for Fish program and Governance Toolkit: Water, respectively). While they differ on specifics, the shared message is clear: water governance arrangements must "recognize those First Nations or their duly created and mandated institutions that have the capacity and capability to develop, administer and enforce their own water laws" (Assembly of First Nations 2012: 2).

\section{Trends in Water Governance Scholarship}

A third factor contributing to momentum for water governance reform is an emphasis within water governance scholarship on the idea that in order for water governance to be equitable and effective, it should be collaborative, and should include affected populations-specifically Indigenous peoples-in shared decision-making processes. These trends are further bolstered by a suite of ecological and social arguments that have also led to rescaling of many water governance institutions and practices to the local watershed level (Bark et al 2012; Cohen 2012; Cronin \& Ostergren 2007; Barnhill 
2009; Jackson et al 2012; Phare 2009; Tipa \& Welch 2006; Brandes \& O'Riordan 2014; Memon \& Kirk 2012). For First Nations, in particular, water governance scholarship and freshwater policy and advocacy communities have increasingly foregrounded the integral role First Nations must play in water governance in BC (Brandes \& Curran 2009; Brandes \& O'Riordan 2014; von der Porten \& de Loë 2013a, 2013b). These shifts are seen as central, not only for First Nations, but for a respectful, equitable and effective water governance future more broadly. 


\section{RESEARCH APPROACH AND METHODOLOGY}

The research for this paper involved a mixed qualitative methods approach. First, indepth work was undertaken with the Lower Similkameen Indian Band (LSIB), a member of the Syilx Nation, with whom there was mutual interest in working together on water governance research. Water is at the forefront of planning in the Similkameen region: the Regional District of the Okanagan-Similkameen is developing a Similkameen Watershed Plan and the LSIB at the time of this research acted on the steering committee for this plan; and the Okanagan Nation Alliance is coordinating the Syilx Water Strategy with the goal to "incorporate Syilx principles and practices associated with water stewardship" (ONA 2014). As part of this collaboration with the LSIB, we conducted semi-structured interviews with natural resource staff and others whose work addresses water, at both the band and tribal alliance level. We also conducted three community circles to better understand community perspectives and concerns in 20122013. To get a sense of other First Nations' experiences and perspectives on collaborative water governance, we also conducted other interviews with natural resource officers from four other First Nations, in addition to observation at several First Nations-led water planning meetings. Interviews (a total of 15) were transcribed and coded; this paper includes quotes as interviewees offered rich insights into the themes explored.

Research also included a document review of First Nations' submissions to the Water Act modernization process (a total of 46 submissions were considered), as well as review of BC First Nations' water declarations and water governance toolkits. This document review provided details and perspective on the broader set of concerns and interactions among various First Nations governments and provincial First Nations leadership around water governance in the province. Any misinterpretations herein are the authors' alone; we do not claim to represent the views of any First Nations involved in this work. 


\section{RESULTS AND DISCUSSION}

\section{Results and Discussion Part 1: What are the Persistent Governance Challenges?}

In order to evaluate the scope and potential of collaborative watershed governance in $\mathrm{BC}$, it is essential to first consider some of the outstanding issues that First Nations identify in the existing colonial water governance framework, as any new approaches to governance will have to contend with - and presumably attempt to address - existing governance barriers. From interviews and document review conducted in this research, we highlight four key governance issues: (1) there are fundamental contestations over jurisdiction and tensions with the Province; (2) the colonial governance framework for water is fragmented and often implicitly or explicitly excludes Indigenous laws and knowledge; (3) capacity and funding are persistent barriers; and (4) there is a deeplyrooted lack of trust between First Nations and colonial governments. After providing this context, we then turn to an analysis of ongoing governance shifts towards collaborative watershed decision-making, and how this approach is likely to articulate with, respond to, or potentially compound, the identified concerns.

\section{Fundamental contestations over jurisdiction and tensions with the Province}

Every time we want to talk with the provincial government we always get labeled as a stakeholder, as an interested party, versus a higher-level government agency that is trying to make high-level decisions. (Okanagan natural resource officer, April 2014)

This natural resource officer speaks to a core tension within the existing colonial water governance framework in BC: the ongoing lack of observation of First Nations' rights and jurisdiction, the Province's assertion of exclusive Crown ownership over water, and the struggle for First Nations to be, as one interviewee stressed, "not consulted but engaged" in decision-making related to water. Many scholars have also commented on the ongoing denial of Indigenous authority and rights and title in colonial environmental governance in Canada (Dalton 2013; Kotaska 2013; McGregor 2013; Sam 2008, 2013; von der Porten \& de Loë 2013a, 2013b, 2014; Walkem 2004). The prominence of this theme throughout this research reinforces that this remains a fundamental, unresolved issue in the realm of water governance in $\mathrm{BC}$.

First Nations in BC have made explicit that their rights to lands, water, and governance have never been ceded, and that they must be engaged as Nations in government-to-government relationships in decision-making related to water:

Where Aboriginal Title and Rights have not been addressed, the Government of British Columbia does not have the title or jurisdiction to assert ownership, 
control or jurisdiction over water (UBCIC 2010: 3. See also UBCIC 2011; AFN 2012; FNLC 2013).

However, despite legal recognition of Aboriginal rights and title, and agreements signed between First Nations leadership bodies with the Province that acknowledge the need for government-to-government relationships and shared decision-making processes ${ }^{7}$, the translation into practice in colonial water governance is not consistently experienced. Many First Nations have voiced their concerns that the consultation and approval process for the WSA failed to uphold this obligation (see, for example: BCAFN 2013; FNS 2013; UBCIC 2011) and that First Nations were lumped in with other 'stakeholders' in providing comments on the legislation (Cowichan Tribes 2010; Haisla Nation Council 2011; McLeod Lake Indian Band 2013; von der Porten \& de Loë 2014). Further to this, analysis of the outcomes of the consultation process has validated that First Nations concerns were not taken seriously, particularly regarding water rights and allocation (McFarlane et al., in process). In its final form, the WSA is silent on Aboriginal rights and title to water.

\section{The colonial governance framework for water is fragmented and excludes Indigenous laws and knowledge}

Decontextualized policies and fragmented lines of accountability stand out as other key water governance challenges. Several interviewees noted that water policies administered by colonial governments do not always respond adequately to local conditions and needs. For instance, a Syilx member related that the drinking water guidelines are not based on specific needs in the Similkameen, but rather on regulations developed elsewhere in Canada that are subsequently 'implanted' locally, particularly given federal involvement in drinking water:

Federally it's not so much an interaction as a dictation. Because there is a new Bill $^{8}$ out that will dictate how Bands will manage their water systems. And Aboriginal Affairs and Northern Development Canada, they set the regulations on that, because we are under the federal government and they deal with things across the country. So it's never anything specific to our area or even to the province because they are looking at things nationally.

This relates to an overarching theme that emerged through interviews and document review - consistent with the work of LaBoucane-Benson et al. (2012) and Walkem (2004), among others - that within colonial water governance systems, there is a lack of

\footnotetext{
${ }^{7}$ In 2005, the Province of BC and BC First Nations entered into a "New Relationship" with the aim to improve government-to-government relations. The accord sets out new processes and structures to work together on decisions over land and resource use, revenue sharing, and economic development (Government of British Columbia 2005).

${ }^{8}$ A reference to Bill S-8, the Safe Drinking Water for First Nations Act, passed in 2013.
} 
consideration for the diverse cultural and spiritual relationships, laws, and forms of governance for water that different First Nations practice and uphold. As one natural resource officer in the Okanagan summarized, "it [current water governance] is still completely missing that other worldview." Various submissions to the Province on the Water Act modernization process spoke directly to this issue, calling for inclusion of Indigenous laws and perspectives in the new Act:

The [Water Sustainability] Act must be updated to reflect the unique and cultural interests that First Nations have with water, and to promote the use of traditional knowledge in water stewardship and decision-making. (FNS 2013: 1)

\section{Capacity and funding are persistent barriers}

Interviewees highlighted funding and capacity challenges ${ }^{9}$ as key constraints that First Nations natural resource staff face in water governance. These capacity limitations in natural resource governance are linked to historical and ongoing colonialism ${ }^{10}$, which are experienced in very concrete ways in terms of insufficient staffing, funding, and time. Water is often just one of a host of responsibilities in a given staff member's portfolio. A fisheries staff person explained:

Even on the First Nations side, people are well intentioned and they are interested. But in some cases when the person is dealing with your water stuff, is a member of council or maybe the Chief, and they are dealing with 10 million other things, it's really hard to have that thoughtful kind of engagement that is really needed for those processes.

Further, capacity to govern water resources not only varies tremendously between individual First Nations and nation or tribal alliances in $\mathrm{BC}^{11}$ but it is also constrained within colonial governments as well. As we will return to later in this paper, we suggest that emphasis also needs to be placed on reversing the gaze of 'capacity development' back to colonial governments, requiring colonial governments to build an understanding of First Nation's laws, language, protocols for working together. In addition, sufficient staff will be needed to effectively engage with each First Nation.

${ }^{9}$ Our interpretation does not suggest that First Nations are 'capacity deficient'; First Nations possess the capacity to govern within their own systems of knowledge and laws, and have and continue to develop capacities to interact with and challenge colonial governance.

${ }^{10}$ The referrals process, for instance, places immense burdens on Indigenous communities' time and resources, and has been described as "one of the greatest logistical difficulties facing Aboriginal communities today" (Morellato 2008: 72)

${ }^{11}$ For example, one First Nation in BC's lower mainland that is developing a watershed strategy has a registered population of 92 members. Total annual federally received funding in 2013 for social, housing, and education programs, community infrastructure and economic development initiatives was reported at $\$ 1.2$ million. Comparatively, an adjacent First Nation, also located in the lower mainland, is developing a marine use plan and has a registered population of 4,176 members with federal funding at $\$ 13.9$ million. 
Fragmentation in colonial water governance also creates capacity challenges. Water cuts across jurisdictions including those of multiple First Nations, in addition to federal, provincial and local governments (not to mention those that cross transnational boundaries, e.g. between Canada and the U.S., see Norman 2012 \& 2015). Within each of these government entities, responsibility for specific aspects of water management is further fragmented between multiple departments. Several interviewees described that it is unclear which authorities are responsible for different aspects of water governance and management, such as monitoring and sharing water quality and quantity information. This fragmentation, they suggested, further constrains the ability to pursue holistic or meaningful water management that serves the needs of First Nations.

\section{Lack of trust}

At the confluence of the issues described above-contested jurisdictions, fragmentation, and capacity challenges-lies the outstanding matter of lack of trust. In the words of a LSIB member, "the distrust is on so many levels and so many ways." Historically, the provincial government has given First Nations little basis to trust that they will be engaged respectfully in water governance, and, as mentioned previously, the WSA was another failure to acknowledge Aboriginal water rights and develop a more meaningful consultation and engagement process (FNS 2013):

First Nations are continually forced into lengthy and costly litigation and other processes to advance their Aboriginal title and rights as a means of protecting the environment against unsustainable development and practices. This perpetuates a relationship with the Crown, and proponents, based on conflict, rather than mutual respect and cooperation (FNS 2013: 8).

Writing of co-governance, Goetze (2005) describes the "crisis of confidence" between First Nations and the province of BC, where "negotiating new relationships must contend with a firmly entrenched legacy of suspicion and distrust" (256). This legacy was evident in this research, and is certain to condition the likely success or outcomes of emerging water governance shifts.

\section{Results and Discussion Part 2: Collaborative Watershed Governance in BC: Implications for First Nations' Engagement in Water Governance}

The previous section detailed existing governance barriers that some First Nations encounter in colonial water governance in BC. It also provided a sense of the 'initial conditions' upon which a collaborative watershed governance approach would need to build, with critical issues including lack of trust, and a system in which non-Indigenous ideas and practices dominate. We now turn to a discussion of how collaborative watershed governance could 'articulate with' these existing governance challenges. Specifically, we consider four key themes: 1) Power sharing and core jurisdictional 
tensions with the Province; 2) Scale of authority and collaboration with local government; 3) Capacity challenges as an impediment to equal First Nations' participation; and 4) ongoing entrenchment in non-Indigenous approaches.

\section{Power sharing and core tensions with the Province over jurisdiction}

From First Nations' initial responses to the WSA's proposal for new forms of governance, as well as based on accounts of experiences with existing collaborative watershed entities, tensions around power sharing and strength and scale of authority in water governance are evident in the relationships between First Nations and the Province.

The Province must not assume it has sole jurisdiction over water, nor that it is the sole authority to delegate management of the water in our traditional territory. Water issues transcend jurisdictional boundaries and are not the responsibility of just one governing body (Cowichan Tribes 2013:1).

Overall, despite the loose suggestion in the WSA legislative proposal of "greater First Nations participation," there is also a clear ongoing adherence to provincial government control:

Ultimate accountability for environmental protection would remain with the provincial government. It would continue to establish and coordinate laws, rules, agreements and financial arrangements, including setting provincial objectives and outcomes. It would also be responsible for deciding the institutions, systems and roles for any delegated responsibilities (MoE 2013: 84).

While the WSA now includes the potential for decision-making under the Act to be delegated to other entities-which could include watershed governance entities-in their submissions to the WSA several First Nations noted concerns around this provision:

It is important to note that the [WSA] proposal does not clearly distinguish between governance and stewardship responsibilities, nor does it indicate which entities (First Nations and other governments, water users, interest groups, etc...) will hold those responsibilities (BCAFN 2013: 23).

A natural resource consultant working in the Similkameen contemplated that the Province does not have the legitimate authority for water on or below First Nations reserves and territories, and that because First Nations have never ceded their governance powers for water, the Province cannot then delegate that authority:

It is interesting because it would have to be that the Nation or Band would have a decision-making authority over whatever decisions are being made...So one of the challenges is well, does the Province even have the authority to delegate any 
governance to First Nations? So they can't really do that...(Okanagan Natural Resource Officer, November 2013).

Relatedly, the question of who has legitimate final authority in collaboratively-governed watershed entities is also a point of contention. For instance, the former National Chair of Aboriginal Economic Development writes in her submission to the WSA: "Working collectively together is important to bring everyone's interest to the table, but in the end, it should be First Nations interests as priority in order to protect their rights enshrined in s. 35 of the Constitution Act" (Sayers 2013: 6).

Goetze (2005), writing on co-governance, notes that such arrangements will only be empowering to the extent that they "facilitate the exercise of power historically held by Aboriginal peoples in managing their resources as autonomous nations" (248). Similarly, the legitimacy and acceptability of watershed entities will rest on the extent to which provisions are made for power-sharing and decision-making authority for First Nations (Kotaska 2013; von der Porten \& de Loë 2013a, 2013b). The development and approval process of WSA itself certainly fell did not create these real shifts in powersharing, and it remains to be seen whether the watershed governance entities that could obtain decision-making authority through the Act will facilitate robust decisionmaking authority for First Nations.

\section{Scale of authority and collaborating with local government}

Dimensions of scale are complicated in considering First Nations' jurisdiction and authority in the context of collaborative watershed governance. Cohen and Davidson (2011) note: "The watershed approach represents both a scaling up from municipalities and a scaling down from nations, states and provinces..." (4). Although these shifts are complex enough in the context of colonial governments, governance rescaling is even more complex with respect to First Nations' authority. As previously described, First Nations are not stakeholders or local governments, but rather function as governments that negotiate with the Crown. At the same time, distinct First Nations have unique ties and governance powers for specific territories. Further, the governance scales and territorial boundaries within which First Nations operate and engage are highly variable and do not necessarily correspond to particular watershed areas. An additional complexity is the issue of overlapping and competing claims to territories between First Nations (Kotaska 2013). As Phare (2011) describes: "In any given region, there may be multiple claims by different First Nations to the waters. These First Nations may have different, and competing values, ranging from conservation-oriented perspectives to development and full exploitation. Further, each First Nation may have a different strength of claim to water rights in an area, and this would have to be determined" (14).

While there is in-depth commentary on the dynamics between the province and First Nations around water governance, less attention has been given to the interactions 
between First Nations and local governments. First Nations and local governments have historically had little interaction with one another (Wells 2004); today, however, more extensive relationships and partnerships are emerging (Abram 2002), including in the realm of watershed governance. Collaboration between First Nations and local governments has its own set of complications. For instance, a First Nations natural resource staff person recounted how differing strengths of authority can hinder working with local governments even when there are mutual intentions to collaborate:

It is good: every band is trying to work with the local municipality the best they can so that they have a better working relationship. And when it comes to issues such as water - that's so big that it has to be there for everybody in the community, Native and non-Native. So they are trying hard to do that. Every time we look at interacting with Regional Districts we have to be very cautious because we can't recognize that level of government...So every time we want to talk with anybody, we have to be very careful with Aboriginal title and rights, and signing over, consultation, and jurisdiction.

The Similkameen provides an interesting case of an existing watershed initiative between local governments and a First Nation. The LSIB and the Regional District of the Okanagan-Similkameen have recently started working together on a Similkameen Watershed Plan. This plan is headed by the Similkameen Valley Planning Society (SVPS), of which the LSIB is a member. While the plan is still in its early phases, and we do not claim to know the full extent of dynamics and relationships involved, it is productive to look at the factors shaping negotiations. A LSIB member described that being part of the SVPS watershed initiative is potentially one step towards having greater influence in decision-making around water: "So obviously the band was very smart and wise to recognize that sitting and being part of the society is strategically very important for saying, 'we want to be a decision-maker in this valley."' This interviewee conveyed that while it is an ongoing struggle to set the terms of engagement, there has been progress:

So I would say we've made some really good ground at that table. I mean they don't sit there and assume that because you are an Indian you approve for the band. They now understand that that is consultation that has to happen at a different level, but we are there and we are participating in this information.

It seems, at least initially, that a key barrier for First Nations in collaborating more broadly in locally-based watershed initiatives is a lack of guidelines or protocols that would not prejudice Aboriginal rights or title claims. Some such protocols and agreements (including the New Relationship Accord and the Kunst'aa Guu Kunst'aayah Haida Reconciliation Protocol) have been agreed to between First Nations and the Province and might help to facilitate collaboration across the multiple scales of 
authority. While the effectiveness of these agreements has fluctuated over time, the commitment to work together, at a minimum, can allow for on-going renewal of the relationship between parties.

\section{Capacity challenges - an impediment to equal First Nations' participation}

As previously discussed, capacity limitations in terms of time, staff, and resources are a significant challenge for many First Nations natural resource departments, often linked to historical and ongoing colonialism. Here, it is useful to turn to Tipa and Welch's (2006) work on collaborative water governance in New Zealand, in which they problematize capacity as an impediment to Indigenous participation in basin governance. These scholars highlight that cooperative management, predicated on the ideal of "interaction between equal partners in decision making" (382) is unsatisfying insofar as it "omits to explain how equal status and equal participation are to be realized when one partner has greater access to funding, staffing, expertise, statutory powers, and functions" (382). Such concerns remain outstanding for the issues under consideration here. For instance, as a First Nations staff person involved in a collaborative watershed entity related:

There is a good shift in understanding [for the Regional District] to realize it is easier to work with us than to not work with us. So it's just a matter of they have tax dollars and capacity to fund that position, whereas for us to have a dedicated person who works in that position with them, we would need to find the capacity for it. So there are still some of those traditional barriers to being able to participate fully into the meaningfulness to that agreement.

Given these realities, there is increasing recognition that resources need to be provided for First Nations to assume a meaningful decision-making role in collaborative watershed governance (Brandes \& O'Riordan 2014; von der Porten \& de Loë 2014), a concern that many First Nations also stress as an outstanding issue in their WSA submissions to the Province (cf. PoWG report, forthcoming). This includes shifting the onus on capacity development for collaboration onto colonial governments, who also maintain a fiduciary responsibility for Aboriginal peoples. We will return to this discussion in section 5 .

\section{The foundations of water governance remain firmly entrenched in non-Indigenous approaches}

While there is recognition that capacity in terms of funding, human resources, and technical knowledge is a prominent concern, Nadasdy (2012) writes that such calls for capacity development have problematic undercurrents:

This same paternalistic subtext is evident in by now taken-for-granted calls in the Canadian self-government discourse for First Nations to build capacity, a euphemism for Euro-Canadian-style training that will enable them to serve as the 
bureaucratic functionaries increasingly required by land claim and selfgovernment agreement as if they had not had the "capacity" to govern themselves before the arrival of Euro-Canadians (529).

Although Nadasdy (2012) is writing of the land claims process in northern Canada, his argument translates into a critique of collaborative watershed governance. We suggest that discussions of capacity in collaborative watershed governance need to be broadened to consider who is directing the process: who is being asked to speak whose language, and on whose terms and knowledge systems is collaborative watershed governance proceeding? With increasing recognition of Aboriginal rights and title, growing prominence given to the notion that interactions between colonial governments and First Nations should be on a government-to-government basis, and a proliferation of natural resource co-governance schemes, First Nations have been forced to work within dominant bureaucratic management systems (Nadasdy 2003a: 2; see also Natcher et al. 2005; Natcher \& Davis 2007). Kotaska (2013) has documented that this has generally held true in emerging co-governance arrangements in $\mathrm{BC}$, where Provincial structures and processes continue to dominate.

Turning to water specifically, given the heightened attention on collaborative water governance with First Nations, First Nations could face an 'onslaught' of requests to participate in collaborative watershed governance processes. One interviewee working on provincial water and fisheries issues articulated preoccupation that First Nations will have to continue to work in a governance framework still premised on nonIndigenous foundations, leaving little space for Indigenous knowledge and conceptualizations of governance:

But the thing that I worry about is that if there gets to be more watershed-based planning and First Nations are engaged at that level, I always just worry about...it's wrong to say the ability or the knowledge that people would need to have coming into a planning process like that or a management process. And again it is sort like the situation where as a First Nations [person], I have to fit into someone else's worldview and how they think or how they manage and how they plan.

So the thing that I worry about is how successful are these things going to be if people come into these processes with different sets of experience and knowledge that may not be recognized by the other parties in the group? But First Nations bring a wealth of knowledge in the knowledge that they have about the landscape and the territory which might not be that compatible. But that doesn't mean that it is not as valuable. So I think it is the knowledge systems that will be used going forward, will they be respected and recognized within the planning process? 
This interviewee raises two key issues that require attention. The first is the concern that First Nations will have to continue to adapt to the terms of water governance processes under the direction of colonial governments, versus placing the onus on colonial governments to support, adapt, or at minimum, follow more closely Indigenousled plans and approaches to water governance. As such, a power imbalance is embedded within the process from the outset. Relatedly, this interviewee raises the question of whether space will exist within watershed entities for First Nations' knowledge and viewpoints to be privileged or at least considered on equal grounds as Euro-centric knowledge. As has been identified in existing co-governance and comanagement schemes, there is concern that Indigenous knowledge will not be treated as a complete knowledge system, but rather distilled from its context into disparate fragments that can easily incorporated into dominant colonial water management structures (Bark et al. 2012; Cruikshank 2004; Nadasdy 2003a, 2003b; Natcher et al. 2005; van Tol Smit et al. 2014). In summary, attention must be directed at who is in control of developing the terms, structures, and decision-making processes of collaborative watershed governance, and if and how Indigenous knowledge are privileged (Kotaska 2013). 


\section{BEYOND COLONIAL WATER GOVERNANCE}

Our research suggests that the imposition of a colonial governance framework has done little to support the inclusion of Indigenous peoples or their knowledge in existing water governance frameworks. Maintaining this framework is no longer viable, particularly given the changing legal landscape in Canada that recognizes Aboriginal rights and title to lands and resources, including the right to manage those lands and resources. While legislative changes introduced in the new WSA may promote First Nations participation in water governance, it remains to be seen whether or not these changes will sufficiently and effectively articulate with the core concerns that First Nations have identified in the existing colonial water governance system.

Based on our document and literature review, in addition to evaluation of concerns raised by interviewees, the following section discusses three alternative pathways for collaborative water governance arrangements. Each is gaining support from Indigenous peoples and in academic and policy circles, and some are already evident across the province in more practical ways as well. Each of these alternatives, it should be noted, assume collaboration, versus resistance (i.e., legal challenges), as a pathway towards improved Indigenous participation in water governance. This is not to invalidate legal challenge as a legitimate avenue for redress and improvement, as we recognize that considerable progress for First Nations has often only proceeded through legal channels. As part of the discussion of alternatives, we also seek to address the enabling conditions or supports needed to effectively restructure the framework and address core tensions, implied by these different, albeit linked, options.

\section{Imagining Alternative Pathways Towards Collaborative Water Governance}

\section{Co-governance}

Co-governance is increasingly attracting greater interest and attention from water governance and legal scholars (see Nowlan \& Bakker 2010; Brandes \& O'Riordan 2014; Wilson 2013) as a means to address some of the key barriers to Indigenous participation within the current water governance framework, such as shifting towards the empowerment of traditionally marginalized stakeholders; the reinforcement of social trust between parties; and the reduction of conflict (Nowlan \& Bakker 2010: 17). Furthermore, co-governance can potentially address core tensions related to authority and power sharing, offering an opportunity for the Province and individual First Nations to define and agree on a process for sharing authority and decision-making over water resources. Generating the terms of the governance process and structures together can create the space to include Indigenous conceptualizations of governance that ultimately may serve to enhance sustainable water governance. 
For example, the shift away from a centralized authority towards more locallybased governance can signal greater inclusion of local and traditional knowledge to inform decision-making, as well as improved access for First Nations to information held by government agencies. For colonial governments, this can mean enhanced community support leading to more positive outcomes for water management and planning.

There are limitations to co-governance, however, particularly around dismantling the power imbalances inherent in colonial governance frameworks. Co-creation of new governance frameworks needs to ensure that the updated model doesn't simply replicate an overly bureaucratic structure that overwhelms each governments' capacities and/or excludes Indigenous knowledge or conceptualizations of governance. An additional challenges with greater and more equitable representation of all parties in a co-governance arrangement is the greater costs involved to support participation. Neither of these limitations, however, precludes co-governance from being a viable alternative for a more equitable and effective collaborative water governance arrangement with Indigenous peoples.

\section{Indigenous Governance}

In the first court case to grant Aboriginal title to lands outside an Indian Reserve, the 2014 Tsilhqot'in decision by the Supreme Court of Canada conferred ownership rights to Aboriginal peoples. These rights include the right to decide how land will be used; the right to economic benefits of the land; and the right to proactively manage the land. This decision clarifies the right for Indigenous peoples to both shape and assert their own forms of governance over their lands and resources in a manner that reflects their values and perspectives (Mandell \& Pinder 2014).

Consequently, one increasingly attractive alternative to address the concerns First Nations have with the existing water governance framework is for First Nations to develop their own water plans and exert their own Indigenous laws over water resources in their titled, reserve, and treaty lands or traditional territories. A number of Indigenous-led water governance initiatives have recently emerged to achieve exactly that. Most recently, the Nadleh Whuten and Stellat'en First Nations have developed and enacted water laws in their traditional territory that they will use to hold government and industry to account (Hoekstra 2016). The intention behind the water policy is not to prohibit industry or development in their traditional territories, but instead to set the terms of reference for government or third parties to meet the water objectives set by the communities.

While the Syilx Water Strategy is still under development, it represents the effort of one Nation to build an Indigenous water governance strategy, where "the themes expected to emerge from this work will be the Syilx perspective on the importance and 
value of water, how it should be used and not used, issues with how water is currently used and strategies to conserve, respect and protect water in Syilx territory" (ONA 2014). One interviewee explained that the Strategy will also be a starting point to set terms of engagement with colonial governments in water governance:

We [the Syilx Nation] will be able to use it [the Syilx Water Strategy] to engage with provincial and federal proponents and regional districts, and say: this is our viewpoint and this is how we want to manage water. Here's our policy, here's our viewpoint, and how are we going to work together to come to these similar levels?

Indigenous assertion of sovereignty over water resources, can result, paradoxically, in both clarifying positions and further complicating jurisdictional authority. As previously mentioned, competing claims over land and resources occur not just between First Nations and colonial governments but also between individual First Nations (Phare 2011). Moreover, will Indigenous-led governance activities be recognized by colonial governments? And does it matter if they are? While dismantling traditional power imbalances inherent in the existing colonial framework may imply that First Nations can only achieve their goals of self-determination by working outside a colonial system, it doesn't, however, imply that they can achieve their goals of water governance. That is, for Indigenous water governance to be respected by other agents-including colonial governments, industry, or other land and water users - it will need to be recognized, at least to some extent. Furthermore, First Nations will need the supplementary resources to enforce their water laws and policies. The persistent challenge this presents is that existing resource and capacity constraints can limit many First Nations' efforts to create their individual water plans, policies and strategies.

\section{Transitional Governance}

In the interim, as the regulations are developed that set out how the governance provisions in the Water Sustainability Act will be interpreted and applied, there needs to be a way for Indigenous and colonial governments to work together: acknowledging fundamental disagreement over authority, jurisdiction, and rights and title, but recognizing the need for improved water management. One model that demonstrates how incremental reconciliation of Provincial and Aboriginal title to water could occur is the Kunst'aa Guu - Kunst'aayah Haida Reconciliation Protocol. In the reconciliation protocol, both the Haida Nation and the Province explicitly acknowledge their competing claims to jurisdiction for Haida Gwaii territory. With these competing claims made clear, the Protocol commits both parties to working together:

Notwithstanding and without prejudice to the aforesaid divergence of viewpoints, the Parties seek a more productive relationship and hereby choose a more respectful approach to coexistence by way of land and natural resource 
management on Haida Gwaii through shared decision-making.

These interim agreements are not intended to resolve outstanding disputes over lands and resources. Instead, they provide a framework to continue to build the relationship between parties and work towards shared interests in land and resource management. In short, they can represent a step towards reconciliation.

\section{Enabling Steps Towards Collaborative Water Governance}

While each of the alternative pathways address one or more of the key concerns raised throughout the interviews and noted in the document review, there remain unresolved tensions. Neither co-governance nor Indigenous governance approaches explicitly reconcile jurisdictional fragmentation and divergent worldviews. And regardless of the approach, additional resources will be needed to further water governance in BC. Consequently, various preconditions need to be met, not only to resolve some of the barriers to First Nations' participation, but also to support the creation of enduring and effective structural change in water governance. As well, it is important to acknowledge that some of these pathways may be fundamentally in tension with each other, so supports may be needed to negotiate any such tensions that emerge as different frameworks are pursued in tandem.

\section{Learning each others' ways}

Through assimilationist policies, such as the Indian Act, First Nations have often been forced to adopt and adapt to colonial laws and institutions that historically excluded their participation. While First Nations are now invited to participate, to some extent, in the current water governance framework, their participation is still constrained by resource and capacity limitations. This is not simply a matter of First Nations lacking the knowledge and capacity but rather a symptom of a structural barrier that prevents equitable participation.

While many First Nations governments would benefit from additional resources invested in capacity for water governance, we suggest that emphasis also needs to be placed on reversing the gaze of capacity development back to colonial governments. This requires colonial governments to build an understanding of each First Nation's laws, language, and protocols for working together. As Tipa and Welch (2006) comment, there is "...an under-theorization of how capacity building is achieved, itself a reflection of a common belief held by local-level agencies that it is primarily if not only indigenous groups that require such enhancement of capacity" (383). Colonial governments and institutions must respond to and learn to work with the many water governance processes and strategies that different First Nations in BC are developing.

Learning together and about each others' water governance processes can have 
the added benefit of enhanced understanding of water systems which may result in improved water management practices. The act of learning together may also help reconcile divergent knowledge systems and worldviews into shared governance practices and decision-making.

\section{Resource and capacity building}

The persistent challenge confronting each alternative pathway to collaborative governance is that resource and capacity will continue to constrain the efforts of many First Nations and colonial governments. For First Nations to participate equally in any given water governance regime, this will mean more than building capacity and adequate resourcing to sustain water governance participation. It might also translate into need for greater coordination and willingness to share resources and knowledge among First Nations. It might also mean collecting resource revenues or entering into resource revenue sharing with the provincial government. For instance, First Nations might collect all or an agreed-upon portion of water licence fees and rentals issued within their traditional territories ${ }^{12}$.

Colonial governments can also face significant resource and capacity shortfalls. From the 2014 Statement of Support for BC Water Sustainability Act and Regulations, the authors recognized the BC government's "financial resources are limited and the new regulations have costly implications" (1). Thus, the authors urged the provincial government to recover sufficient funds from water users in the province through the increase in water license pricing in order to support full implementation of the WSA.

Access to adequate and sustained sources of funding and capacity will be critical to both First Nations and colonial governments in advancing not only preferred but enduring pathways to water governance. The resources considerations are particularly crucial if we take seriously the requirements of meaningful and engaged collaborative processes-a time and resource intensive endeavor.

\section{Restoring trust and reconciliation}

"The ultimate objective [of reconciliation] must be to transform our country and restore mutual respect between peoples and nations." (TRC 2015: 19)

At the heart of moving forward together are the basic requirements of time and relationship building to move beyond the "crisis of confidence" (Goetze 2005) and establish trust and capacities for collaboration. This must happen at multiple levels, from the personal to the institutional. As one interviewee highlighted:

\footnotetext{
12 These revenue sharing arrangements have strengthened support with the Tsilhqot'in decision, whereby First Nations have the right to the economic benefits of the land (Tsilhqot'in Nation v. British Columbia 2014 SCC 44, para. 73) and whereby the Province currently collects fees and rentals from water resources in First Nations traditional territories.
} 
It's about relationship building and understanding different perspectives and what other peoples' needs and drivers are. And how they communicate. To me that is always the most important part of the process: if you can spend the time building the relationship without worrying too much about what the objectives are, or without trying to work to something.

Perhaps the best resource for understanding how to restore trust and build the capacity for working together is the recent report from the Truth and Reconciliation Commission (TRC). This report highlights the core tensions in the relationship between Indigenous and colonial societies, albeit through context of the Indian Residential Schools in Canada. However, the TRC report provides significant insight into going forward "in a manner that overcomes conflict and establishes a respectful and healthy relationship among people" (3). The range of the barriers to Indigenous participation in water governance, including exclusion, resource constraints, and deeply rooted lack of trust, suggests that reconciliation of the relationship between the colonial governments and Indigenous peoples may not only be a pre-condition, but the basis for creating enduring and effective water governance. 


\section{CONCLUSION}

Against the backdrop of growing interest in collaborative watershed governance with First Nations in BC, including in the newly enacted Water Sustainability Act, this article addressed the question: Based on the existing state of colonial water governance in BC, what are some of the implications of collaborative watershed governance for First Nations' water governance concerns and goals? This research has determined that in $\mathrm{BC}$ the existing colonial water governance framework (1) is fragmented with respect to jurisdictional authority; (2) often excludes Indigenous laws and knowledge; (3) lacks capacity and funding for First Nations equitable participation; and (4) remains firmly entrenched in colonial, or non-Indigenous, approaches. Underlying all of these concerns are lack of trust and a fundamental contestation over sovereignty of water in BC. Unresolved, this undermines the legitimacy and potential of the new WSA and collaborative governance arrangements that may be supported by the Act.

This paper subsequently considered how collaborative watershed governance with First Nations might respond to and/or further embed some of these challenges. Specifically, we considered narratives around capacity and implications of ongoing colonial control. To date, there has been little challenge to existing power imbalances: colonial governments remain in control of water governance processes, and resource and capacity imbalances are an impediment to equal Indigenous participation in collaborative watershed efforts.

Building more equitable and effective water governance in $\mathrm{BC}$ will require fundamental transitions away from the existing colonial water governance framework. However, the geographical, cultural, and linguistic diversity of BC's 203 First Nations indicates there cannot be one prescriptive approach to reconciling competing claims to land and water within one set governance structure. Yet, it is possible to envision new arrangements that would both explicitly acknowledge competing Indigenous and Provincial claims to water and establish clear terms for "a more respectful approach to coexistence" through shared decision-making. This, of course, will require a long-term commitment to work together as any approach will experience "cycles of change" (Alfred 2009) and ongoing renewal. 


\section{REFERENCES}

Abram, J. (2002). Building Relationships between First Nations and Local Governments. In Speaking Truth to Power III: A Treaty Forum: British Columbia Treaty Commission.

Alfred, T. (2009). Wasáse: Indigenous Pathways of Action and Freedom. Peterborough, ON: Broadview Press.

Assembly of First Nations (AFN). (2012). Assembly of First Nations Submission to the Standing Senate Committee on Aboriginal Peoples re. Bill S-8: Safe Drinking Water for First Nations Act. Available: http://www.afn.ca/uploads/files/water/afn-s8submission.pdf.

Bark, R., Garrick, D., Robinson, C., \& Jackson, S. (2012). Adaptive Basin Governance and the Prospects for Meeting Indigenous Water Claims. Environmental Science \& Policy, 19-20: 169-177. doi: 10.1016/j.envsci.2012.03.005

Barnhill, K. (2009). Negotiating Sacred Space: Indigenous Participation in Local Environmental Governance. (MS thesis), College of Environmental Science and Forestry, State University of New York.

Bartlett, R. (1998). Aboriginal Water Rights in Canada: A Study of Aboriginal Title to Water and Indian Water Rights. Calgary: Canadian Institute of Resources Law.

Basdeo, M., \& Bharadwaj, L. (2013). Beyond Physical: Social Dimensions of the Water Crisis on Canada's First Nations and Considerations for Governance. Indigenous Policy Journal, 13(4): 1-14.

Blackstock, M. (2001). Water: A First Nations' Spiritual and Ecological Perspective. BC Journal of Ecosystem Management, 1: 54-66.

Boelens, R. (2014). Cultural Politics and the Hydrosocial Cycle: Water, power and identity in the Andean highlands. Geoforum, 57: 234-247.

Borrows, J. (1997). Living between Water and Rocks: First Nations, Environmental Planning and Democracy. University of Toronto Law Journal, 47(4): 417-468.

Brandes, O., \& Curran, D. (2009). Setting a New Course in British Columbia Water Governance: Reform Options and Opportunities. University of Victoria, B.C.: POLIS Project on Ecological Governance.

Brandes, O., \& O'Riordan, J. (2014). A Blueprint for Watershed Governance in British Columbia. University of Victoria, B.C.: POLIS Water Sustainability Project.

British Columbia Assembly of First Nations (BCAFN). (2010). Section 3.31: Water. In 
BCAFN Governance Toolkit: A Guide to Nation Building: 443-462.

British Columbia Assembly of First Nations (BCAFN). (2013). Water Sustainability Act Legislative Proposal. Submission Letter to the BC Ministry of Environment, Water Stewardship Division. December 2, 2013. Unpublished. Available at: https://engage.gov.bc.ca/watersustainabilityact/files/2013/12/BC-Assembly-of-FirstNations.pdf

Budds, J., \& Hinojosa, L. (2012). Restructuring and Rescaling Water Governance in Mining Contexts: The Co-production of Waterscapes in Peru. Water Alternatives, 5(1): 119-137.

Cohen, A., \& Davidson, S. (2011). The Watershed Approach: Challenges, Antecedents, and the Transition from Technical Tool to Governance Unit. Water Alternatives, 4(1): $1-14$.

Cohen, A. (2012). Rescaling Environmental Governance: Watersheds as Boundary Objects at the Intersection of Science, Neoliberalism, and Participation. Environment and Planning A, 44(9): 2207-2224. doi:10.1068/a44265

Coulthard, G. (2007). Subjects of Empire: Indigenous Peoples and the 'Politics of Recognition' in Canada. Contemporary Political Theory, 6(4): 437-460. doi:10.1057/palgrave.cpt.9300307

Cowichan Tribes. (2010). Water Act Modernization. Submission Letter to the BC Ministry of Environment, Water Stewardship Division. June 3, 2010. Unpublished. Available at: https://engage.gov.bc.ca/watersustainabilityact/files/2013/10/CowichanTribes.pdf.

Cowichan Tribes. (2013). Re. Proposed Water Sustainability Act Legislative Proposal. Submission Letter to BC Minister of Environment. December 2, 2013. Available at: https://engage.gov.bc.ca/watersustainabilityact/files/2013/12/Cowichan-Tribes.pdf.

Cronin, A., \& Ostergren, D. (2007). Democracy, Participation, and Native American Tribes in Collaborative Watershed Management. Society \& Natural Resources, 20(6): 527-542. doi: 10.1080/08941920701338059

Cruikshank, J. (2004). Do Glaciers Listen?: Local Knowledge, Colonial Encounters, and Social Imagination. Vancouver, BC: UBC Press.

Dalton, Z. (2013). First Nations and Canada's Species at Risk Act: Moving Towards CoShaping the Species at Risk Agenda. In E. Simmons (Ed.), Indigenous Earth: Praxis and Transformation. Penticton, BC: Theytus Books.

First Nations Fisheries Council (FNFC). (2016). About Water for Fish. Available: http://www.fnfisheriescouncil.ca/initiatives/water-for-fish/about/. 
First Nations Leadership Council (FNLC). (2011). Open Letter: First Nations Leadership Council Concerns on Water Act Modernization. Unpublished. Available: http://www.ubcic.bc.ca/News_Releases/UBCICNews03161101.html\#axzz46UMGbg DT

First Nations Leadership Council (FNLC). (2013). Water Sustainability Act Proposal. Submission Letter to the BC Ministry of Environment, Water Stewardship Division. December 2, 2013. Unpublished. Available at: https://engage.gov.bc.ca/watersustainabilityact/files/2013/12/First-NationsLeadership-Council.pdf.

First Nations Summit. (2010). Water Act Modernization Initiative. Submission Letter to the BC Ministry of Environment, Water Stewardship Division, April 30, 2010. Unpublished. Available at: https://engage.gov.bc.ca/watersustainabilityact/files/2013/10/First-NationsSummit.pdf.

Fraser Basin Council (FBC). (2012). Collaborative Watershed Governance Accord. Available: http://www.fraserbasin.bc.ca/water_cwg_accord.html.

Getches, D. (2005). Defending Indigenous Water Rights with the Laws of Dominant Culture. In D. Roth, R. Boelens \& M. Zwarteveen (Ed.) Liquid Relations, 44-65. New Jersey: Rutgers University Press.

Goetze, T. (2005). Empowered Co-management: Towards Power-Sharing and Indigenous Rights in Clayoquot Sound, BC. Anthropologica, 47(2): 247-265. doi:http://www.jstor.org/stable/25606239

Government of British Columbia. (2005). The New Relationship Accord. Available: http://www2.gov.bc.ca/assets/gov/environment/natural-resourcestewardship/consulting-with-first-nations/agreements/otherdocs/new_relationship_accord.pdf.

Haisla Nation Council. (2011). Response to Policy Proposal on WSA. Submission Letter to the BC Ministry of Environment, Water Stewardship Division. March 14, 2011. Unpublished. Available at: https://engage.gov.bc.ca/watersustainabilityact/files/2013/10/Haisla-NationCouncil.pdf

Hoekstra, G. (2016). Nadleh Whut'en and Stellat'en hereditary leaders proclaim B.C.'s first aboriginal water laws. The Vancouver Sun, March 30, 2016. Available at: http://www.vancouversun.com/business/Nadleh+Whut+Stellat+hereditary+leaders+pr oclaim+first+aboriginal+water+laws/11819121/story.html? Isa=e096-6116

Jackson, S., Tan, P., Mooney, C., Hoverman, S., \& White, I. (2012). Principles and 
Guidelines for Good Practice in Indigenous Engagement in Water Planning. Journal of Hydrology, 474: 57-65. doi: 10.1016/j.jhydrol.2011.12.015

Kotaska, J. (2013). Reconciliation 'at the end of the day' : Decolonizing Territorial Governance in British Columbia after Delgamuukw. (PhD Dissertation), Resource Management and Environmental Studies, University of British Columbia.

Kunst'aa Guu - Kunst'aayah Reconciliation Protocol. (2009). Available at http://www.haidanation.ca/Pages/Agreements/pdfs/Kunstaa\%20guu_Kunstaayah_Ag reement.pdf

LaBoucane-Benson, P., Gibson, G., Benson, A., \& Miller, G. (2012). Are We Seeking Pimatisiwin or Creating Pomewin? Implications for Water Policy. International Indigenous Policy Journal, 3(3): 1-22.

Madill, D. (1981). British Columbia Indian Treaties in Historical Perspective. Indian and Northern Affairs Canada. Retrieved 11/05/2015 from: http://www.aadncaandc.gc.ca/eng/1100100028952/1100100028954.

Mandell and Pinder. (2014). Tsilhqot'in Nation v. British Columbia 2014 SCC 44 Case Summary.

Available: http://fnbc.info/sites/default/files/job/Tsilhqot\%27in\%20Nation\%20v\%20British\%20Col umbia\%202014\%20SCC\%2044.pdf

Mascarenhas, M. (2007). Where the Waters Divide: First Nations, Tainted Water and Environmental Justice in Canada. Local Environment, 12(6): 565-577.

Matsui, K. (2009). Native peoples and water rights: Irrigation, dams, and the law in Western Canada. Vol. 55. Montreal: McGill-Queen's University Press.

McFarlane et al, in process.

McGregor, D. (2012). Traditional Knowledge: Considerations for Protecting Water in Ontario. International Indigenous Policy Journal, 3(3): 1-21.

McGregor, D. (2013). Indigenous Knowledges and Environmental Ethics: From Guidelines to Governance. In E. Simmons (Ed.), Indigenous Earth: Praxis and Transformation. Penticton, BC: Theytus Books.

McLeod Lake Indian Band. (2013). Water Sustainability Act Legislative Proposal. Submission Letter to the BC Ministry of Environment, Water Stewardship Division. November 19, 2013. Unpublished. Available: https://engage.gov.bc.ca/watersustainabilityact/files/2013/11/McLeod-Lake-IndianBand.pdf

Memon, P., \& Kirk, N. (2012). Role of Indigenous Mãori People in Collaborative Water 
Governance in Aotearoa/New Zealand. Journal of Environmental Planning and Management, 55(7): 941-959. doi: 10.1080/09640568.2011.634577

Ministry Of Environment (MoE). (2013). A Water Sustainability Act for BC: Legislative Proposal. Available:

https://engage.gov.bc.ca/watersustainabilityact/files/2013/10/WSA_legislativeproposal_web-doc.pdf.

Morellato, M. (2008). The Crown's Constitutional Duty to Consult and Accommodate Aboriginal and Treaty Rights. West Vancouver, BC: National Centre for First Nations Governance.

Nadasdy, P. (2003a). Hunters and Bureaucrats: Power, Knowledge, and Aboriginalstate Relations in the Southwest Yukon. Vancouver, BC: UBC Press.

Nadasdy, P. (2003b). Reevaluating the Co-Management Success Story. Arctic, 56(4): 367-380.

Nadasdy, P. (2012). Boundaries Among Kin: Sovereignty, the Modern Treaty Process, and the Rise of Ethno-territorial Nationalism among Yukon First Nations. Comparative Studies in Society and History, 54(3): 499-532.

Natcher, D., Davis, S., \& Hickey, C. (2005). Co-Management: Managing Relationships, Not Resources. Human Organization, 64(3): 240-250.

Natcher, D., \& Davis, S. (2007). Rethinking Devolution: Challenges for Aboriginal Resource Management in the Yukon Territory. Society \& Natural Resources, 20(3): 271-279. doi: 10.1080/08941920601117405

Norman, E. (2012). Cultural Politics and Transboundary Resource Governance in the Salish Sea. Water Alternatives, 5(1): 138-160.

Norman, E. (2015). Governing Transboundary Waters Canada, the United States and Indigenous Communities. New York and London: Routledge Press.

Nowlan, L., \& Bakker, K. (2007). Delegating Water Governance: Issues and Challenges in the BC Context. Vancouver, BC: BC Water Governance Project.

Nowlan, L., \& Bakker, K. (2010). Practising Shared Water Governance in Canada: A Primer. Vancouver, BC: UBC Program on Water Governance.

Okanagan Nation Alliance (ONA). (2014). Water Strategy. Available: http://www.Syilx.org/operations/natural-resourcesland-use/water/.

Passelac-Ross, M, \& Buss, K. (2011). Water Stewardship in the Lower Athabasca River: Is the Alberta Government Paying Attention to Aboriginal Rights to Water? Journal of Environmental Law and Practice, 23(1): 69-83. 
Perreault, T. (2005). State Restructuring and the Scale Politics of Rural Water Governance in Bolivia. Environmental Planning A, 37(2): 263-284.

Perreault, T. (2008). Custom and Contradiction: Rural Water Governance and the Politics Of Usos Y Costumbres in Bolivia's Irrigators' Movement. Annals of the Association of American Geographers, 98(4): 834-854.

Phare, M.-A. (2009). Denying the Source: the Crisis of First Nations Water Rights. Surrey, B.C.: Rocky Mountain Books.

Phare, M.-A. (2011). Restoring the Lifeblood: Water, First Nations and Opportunities for Change: Background Report. Toronto, ON: Walter and Duncan Gordon Foundation.

Plummer, R., \& Fitzgibbon, J. (2004). Co-management of Natural Resources: a Proposed Framework. Environmental Management, 33(6): 876-885.

Program on Water Governance, forthcoming.

Rizvi, Z., Adamowski, J., \& Patrick, R. J. (2013). First Nations Capacity in Quebec to Practice Integrated Water Resources Management. International Journal of Water, 7(3): 161-190.

Sam, M. (2008). Water Governance and First Nations. Paper presented at the Okanagan Water Stewardship Council Workshop, Kelowna, BC.

Sam, M. (2013). Indigenous Water Rights: From the Local to the Global Reality. In E. Simmons (Ed.), Indigenous Earth: Praxis and Transformation. Penticton, BC: Theytus Books.

Sanderson, C. (2008). Nipiy wasekimew/clear water: The Meaning of Water, from the Words of the Elders the Interconnections of Health, Education, Law, and the Environment. (PhD thesis), Simon Fraser University.

Sayers, J (2013). Proposed BC Water Sustainablity Act Impacts on First Nations. Submission letter to BC Ministry of Environment. Available:

Singh, N. (2006). Indigenous Water Management Systems. Society \& Natural Resources, 19(4): 357-366.

Statement of Support. (2014). Statement of Support for B.C. Water Sustainability Act and Regulations.

Available: http://poliswaterproject.org/sites/default/files/Statement $\% 20$ of\%20Support $\% 20$ for $\% 20$ WSA.pdf

Tipa, G., \& Welch, R. (2006). Comanagement of Natural Resources: Issues of Definition From an Indigenous Community Perspective. The Journal of Applied Behavioral Science, 42(3): 373-391. 
Thorson, J. E., Britton, S., \& Colby, B. G. (2006). Tribal Water Rights: Essays in Contemporary Law, Policy, and Economics. Tuscon AZ: University of Arizona Press.

Toussaint, S., Sullivan, P., and Yu, S. (2005). Water Ways in Aboriginal Australia: An Interconnected Analysis. Anthropologial Forum, 15(1): 61-74.

Truth and Reconciliation Commission of Canada. (2015). Canada's residential schools: the final report of the Truth and Reconciliation Commission of Canada. McGillQueen's University Press, vol.6.

Union of British Columbia Indian Chiefs (UBCIC). (2010). Water Act Modernization Initiative. Submission to the Ministry of Environment, Water Stewardship Division, Government of British Columbia.Unpublished. Available: http://www.ubcic.bc.ca/News_Releases/UBCICNews04301001.htm\#axzz46UMGbgD $\mathrm{T}$.

Union of British Columbia Indian Chiefs (UBCIC). (2011). UBCIC Submission to Standing Senate Committee on Aboriginal Peoples re. Bill S-11. Unpublished. Available:

http://d3n8a8pro7vhmx.cloudfront.net/ubcic/legacy_url/1112/UBCICSubmissiontoSen ate_S11_020911.pdf?1426350934.

Union of British Columbia Indian Chiefs (UBCIC). (2015). UBCIC Submission to Premier Clark and Minister Polak re. UBCIC Resolution 2015-21, Aboriginal Title and the Water Sustainability Act.

van Tol Smit, E., de Loë, R., \& Plummer, R. (2014). How Knowledge is Used in Collaborative Environmental Governance: Water Classification in New Brunswick, Canada. Journal of Environmental Planning and Management, 1-22. doi: 10.1080/09640568.2013.860017

von der Porten, S. (2012). Canadian Indigenous Governance Literature: A Review. AlterNative: An International Journal of Indigenous Peoples, 9(1): 1-14.

von der Porten, S., \& de Loë, R. (2013a). Collaborative Approaches to Governance for Water and Indigenous Peoples: A Case Study from British Columbia, Canada. Geoforum, 50: 149-160. doi:10.1016/j.geoforum.2013.09.001

von der Porten, S., \& de Loë, R. (2013b). Water Governance and Indigenous Governance: Towards a Synthesis. Indigenous Policy Journal, XXIII(5): 1-12.

von der Porten, S., \& de Loë, R. (2014). Water Policy Reform and Indigenous Governance. Water Policy, 16(2): 222-243. doi: 10.2166/wp.2013.046

Walkem, A. (2004). Lifeblood of the Land: Aboriginal Water Rights in British Columbia. Semiahmoo Reserve: Surrey BC: Environmental Aboriginal Guardians through Law 
and Education.

Walkem, A. (2007). The Land Is Dry: Indigenous Peoples, Water, and Environmental Justice. In K. Bakker (Ed.) Eau Canada, 311-329. Vancouver: UBC Press.

Wells, M. (2004). Structuring Collaboration amongst B.C. First Nations and Local Governments: Learning from Katzie First Nation and Neighbouring Local Governments. (MA thesis), School of Community and Regional Planning, University of British Columbia.

Wilson, P. (2013). The blue paper: Water co-governance in Canada. Forum for Leadership on Water.

Wilson, N. J. (2014). Indigenous Water Governance: Insights from the Hydrosocial Relations of the Koyukon Athabascan Village of Ruby, Alaska. Geoforum, 57: 1-11. 